Hydrology and Earth System Sciences, 6(4), 753-762 (2002) C $\quad$ EGS

\title{
Influence of the Yesa reservoir on floods of the Aragón River, central Spanish Pyrenees
}

\author{
J.I. López-Moreno, S. Beguería and J.M. García-Ruiz \\ Instituto Pirenaico de Ecología, CSIC, Campus de Aula Dei, Apartado 202, 50080-Zaragoza, Spain
}

Email for corresponding author: humberto@ipe.csic.es

\begin{abstract}
The Yesa reservoir, the largest Pyrenean reservoir, was constructed in 1959 to supply water to new irrigated areas in the Ebro Depression, NE Spain. It is filled from October to May-June and then releases large quantities of water in the summer via the Bardenas Canal. The results confirm that the frequency of floods downstream of the dam decreased. The reduction mainly depends on two factors: i) the water storage level, and ii) the season of the year. Floods are very well controlled when the reservoir level is lower than $50 \%$. Between 50 and $70 \%$, only the highest floods are controlled. Finally, the reservoir retains mainly autumn and spring floods; most winter floods are released downstream to ensure the safety of the dam.
\end{abstract}

Keywords: reservoir, flood control, flood seasonality, flood frequency, river regime, Pyrenees

\section{Introduction}

The construction of large reservoirs has increased in recent decades. In 1994, more than 1242 reservoirs were under construction, of which $6.36 \%$ were higher than $100 \mathrm{~m}$ (Takeuchi, 1998). They regulate discharge for many purposes including provision of water for cities and industries, producing hydropower and supplying large irrigation areas in seasonally contrasted climates. Reservoirs cause important changes in river regime downstream (Higgs and Petts, 1988; Jiongxing, 1990), at different time scales. For example, in Mediterranean areas, reservoir discharge is reduced in the wet season; water reserves increase in autumn and spring and are released in summer (López-Moreno, et al., 2000; García-Ruiz et al., 2001). Sometimes, reservoirs are managed to reduce the effect of floods downstream of the dams, by avoiding the coincidence of floods from tributaries of the same river. In other cases, floods contribute decisively to the refilling of reservoirs. The influence of reservoirs on river regimes and floods depends on the purpose of the reservoir, the seasonality of high and low discharges and the state of the reservoir when a flood occurs.

This paper analyses the effect of the Yesa reservoir on floods in the Aragón river and the variability of flood control capacity throughout the year. Yesa is the largest Pyrenean reservoir and was constructed in 1959 for irrigation purposes. Water storage is managed to reach a maximum at the end of spring, which brings about complex interactions between the process of infilling and the occurrence of floods. In the context of the new Spanish Hydrological Plan the Yesa reservoir will be enlarged to three times its present capacity. This implies further changes in the flow pattern and subsequent changes in erosion, deposition and sediment transport downstream.

\section{The study area}

The Yesa reservoir drains an area of $2,181 \mathrm{~km}^{2}$ in the Upper Aragón River Basin (Fig.1), the altitude of which ranges from more than $2500 \mathrm{~m}$ in the north of the basin (Collarada Peak, $2886 \mathrm{~m}$ ) to less than $500 \mathrm{~m}$ at the reservoir. The Aragón river runs north-south across a paleozoic area (limestones, shales and clays), the Inner Sierras (limestones and sandstones) and the Flysch Sector. Then it reaches the Inner Depression (marls) and runs westward to the Yesa reservoir. Downstream of the reservoir, the Aragón river runs southward and flows into the Ebro river. 


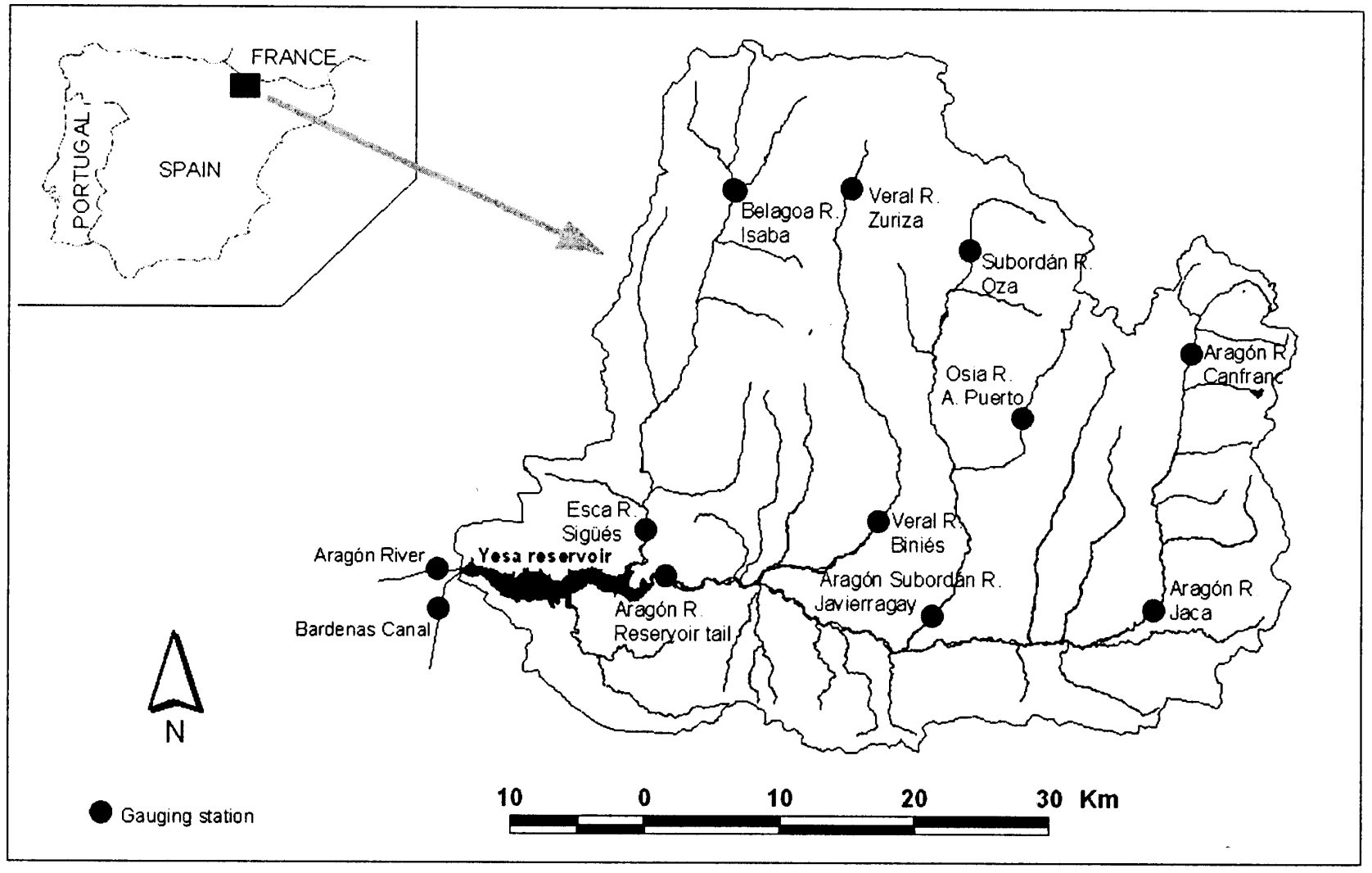

Fig.1. The study area

The Aragón River Basin occupies a transition area between the Atlantic (north and west) and Mediterranean (south and east) climatic influences. The average annual precipitation in the northernmost sector of the basin is over $1500 \mathrm{~mm}$, with around $800 \mathrm{~mm}$ in the Inner Depression. The interannual variability is very high. The wet season is from October to June, with most precipitation in autumn and, secondarily, in spring. Winter rainstorms are important only in the north and northwestern part of the basin, where oceanic influences prevail.

During the cold season (from November until April) the $0^{\circ} \mathrm{C}$ isotherm occurs at 1549 masl. (García-Ruiz et al., 1985), which implies that snow accumulation and melt play a very important role in the monthly distribution of discharges. The high annual variability of precipitation increases the uncertainty of the reservoir filling completely. Intense rainfall can occur at any time of the year (García-Ruiz et al., 2001; White et al., 1997), though its frequency and intensity are higher in autumn.

Human activities in the area have changed much during the 20th century. Most of the cultivated fields have been abandoned (except in the Inner Depression) and are colonised by shrubs or reforested with pines. Natural forests occur above 1400 masl. The subalpine belt (over $1800 \mathrm{~m}$ ) comprises grasslands and small forests of Pinus uncinata and the alpine belt begins around $2300 \mathrm{~m}$.

The Yesa dam is $74 \mathrm{~m}$ high. The original capacity of the reservoir, $470 \mathrm{hm}^{3}$, was recalculated by bathymetry in 1986 to be $450 \mathrm{hm}^{3}$ (CEDEX, 1988), which implies an annual mean siltation rate of $0.79 \mathrm{hm}^{3}$. The main aim of the reservoir is to supply irrigation water for 60,701 ha via the Bardenas Canal, which begins at the foot of the Yesa dam. Upstream and downstream floods are measured by gauging stations where the main rivers (Aragón and Esca) reach the Yesa reservoir and at the foot of the dam.

Figure 2 shows the regimes of the Aragón river (at the head of the reservoir), the Esca river (at Sigüés) and the total inflow into the reservoir. The Esca river clearly has an oceanic regime, with high flows between December and April (maximum in February) coinciding with an increase in fronts from the Atlantic Ocean. The mean contribution of this river to the Yesa reservoir is $353 \mathrm{hm}^{3}\left(12.1 \mathrm{~m}^{3} \mathrm{~s}^{-1}\right)$. There is no evidence of snow influence. Floods occur mainly in winter, mostly in February. The sluice gates of the reservoir have a maximum capacity for a flood of 2240 $\mathrm{m}^{3} \mathrm{~s}^{-1}$ (maximum peakflow recorded was $1560 \mathrm{~m}^{3} \mathrm{~s}^{-1}$ in November 1966).

The Aragón river contributes $1019 \mathrm{hm}^{3}$ per year $(32.6$ $\mathrm{m}^{3} \mathrm{~s}^{-1}$ ) to the reservoir. It has high discharges in spring, when snowmelt coincides with a secondary maximum of 


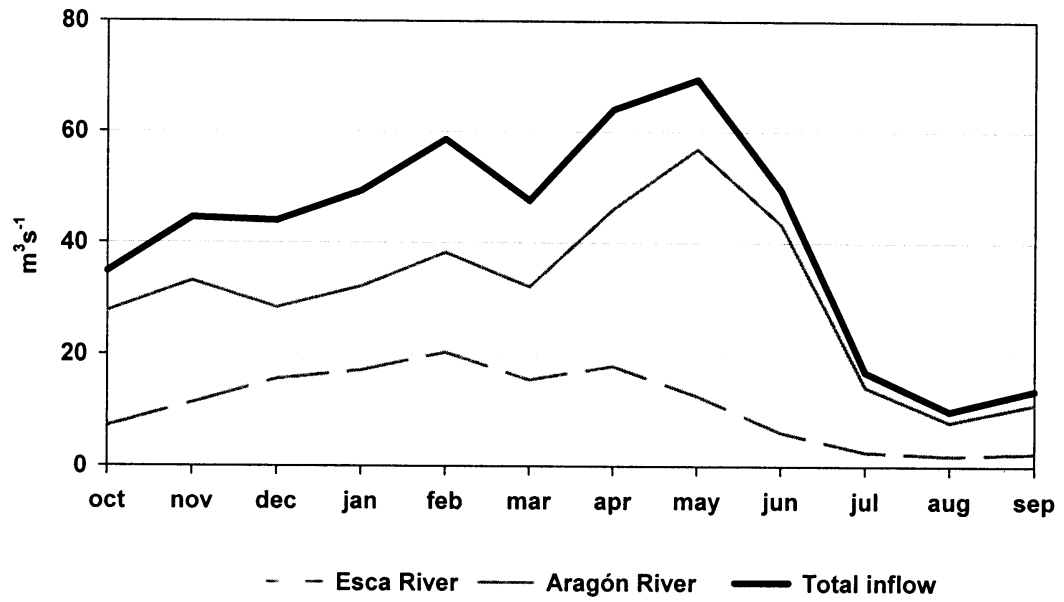

Fig.2. Mean inflow contributions to the Yesa Reservoir (Aragón and Esca rivers, and the total inflow)

precipitation and its flow decreases sharply after June. There is a long period of relatively high discharge in autumn and winter, especially in November and February. Snow retention in the headwaters reduces winter discharges (García-Ruiz et al., 1986, 2001). Floods are more frequent in April and May, though the most extreme floods tend to occur in November.

The total contribution of both rivers to the reservoir is $1372 \mathrm{hm}^{3}$ per year $\left(44 \mathrm{~m}^{3} \mathrm{~s}^{-1}\right)$. The input regime is dominated by that of the Aragón river but with a secondary maximum in February influenced by the high flows of the Esca river. Thus, the ratio of reservoir capacity to inflow is 0.33 .

\section{Methods}

Information about the reservoir regime was provided by the Ebro River Hydrographic Administration (Confederación Hidrográfica del Ebro). Gauge stations provided daily measurements of the Aragón river discharge at the head of the reservoir and of the Esca river. The discharges of both rivers comprise most of the inflow to the reservoir. Direct rain on the inundated surface and the contribution of ephemerally flowing ravines in storm events could not be measured but were likely to be low. The outflow was the sum of the Aragón river at Yesa (downstream of the dam) and the water diverted to the Bardenas Canal. Evaporation was a small portion of the total annual outflow (García Ruiz et al.,1985) and was not considered.

The effects of the Yesa reservoir on floods can be studied: (i) by comparing the daily measurements from 1914 to 2000 before and after the construction of the reservoir in 1959, or (ii) by comparing the daily data between the inflow and outflow series from 1959-2000 (since the construction of the reservoir). The first option does not avoid the problem of medium term climatic trends, while the second can be used to compare the information upstream and downstream of the reservoir using the same time-series. Some authors have simulated upstream and downstream hydrographs to compare the same flood conditions (Lee et al., 2001). In this paper, the inflow and outflow series have been compared. For a general assessment of the effects of the reservoir on the regime of the Aragón river, the magnitudefrequency relationship has been calculated using the empirical equation of Hosking (1990):

$$
P_{x}=\left(i_{x}-0,35\right) / N
$$

where $i_{x}$ is the position of the observation in the series, $N$ the total number of observations, and $P_{x}$ the probability of event $x$.

To assess the effects of the reservoir in controlling floods, the return periods of floods have been calculated by adjusting the Partial Duration Series over the 97th percentile to a General Pareto Distribution (Madsen et al., 1997).

The differences between inflow and outflow at different forage levels have been evaluated by a univariate ANOVA. Three types of floods were distinguished:

(i) Small, very frequent floods, with daily discharges three times higher than the mean annual inflow discharge. This threshold was exceeded, on average, on 18.8 days per year.

(ii) Medium floods, with daily discharges five times higher than the mean annual inflow discharge. This threshold was exceeded, on average, on 3.8 days per year.

(iii) Large, exceptional floods, with daily discharges ten times higher than the mean annual inflow discharge. This threshold was exceeded on an average of 0.6 days per year. 
These thresholds were used to identify all the floods upstream and downstream of the reservoir during the study period. During a long period of continuous floods, individual floods were distinguished when there was at least three days between peakflows and the discharge had decreased by more than $30 \%$. Because of the delay between inflow and outflow floods, a three-day margin was considered in the outflow floods after an inflow flood had been identified..

The average number of floods per month was calculated for both inflow and outflow discharges to compare the seasonal effect.

\section{Results and discussion}

\section{SEASONAL REGIME}

Figure 3 shows the pattern of outflows from the Yesa reservoir throughout the year, distinguishing between the Aragón river and the Bardenas Canal. The curves have opposite trends since the Aragón river has high downstream discharges from November to April, whereas the Bardenas Canal has very low discharges from October to April and high discharges from May to August. Curiously, downstream of the reservoir, the Aragón conforms to an oceanic regime similar to that of the Esca. This suggests that the Yesa reservoir retains most of the high discharges of the Aragón (basically in autumn and spring; López-Moreno et al., 2000).

The water storage level (Fig. 4) begins to rise in October. The maximum stored volume is reached in May and June to satisfy the high water demands in summer when inflows are very low. Storage levels increase greatly in autumn and spring. In winter, most of the inflow is released as a safety measure against spring floods. During summer the stored volume decreases quickly from July to September.

\section{INFLOW AND OUTFLOW DISCHARGES}

Figure 5 shows the frequency-intensity curves of the inflow to the Yesa reservoir and the discharge to the Aragón river downstream of the dam.

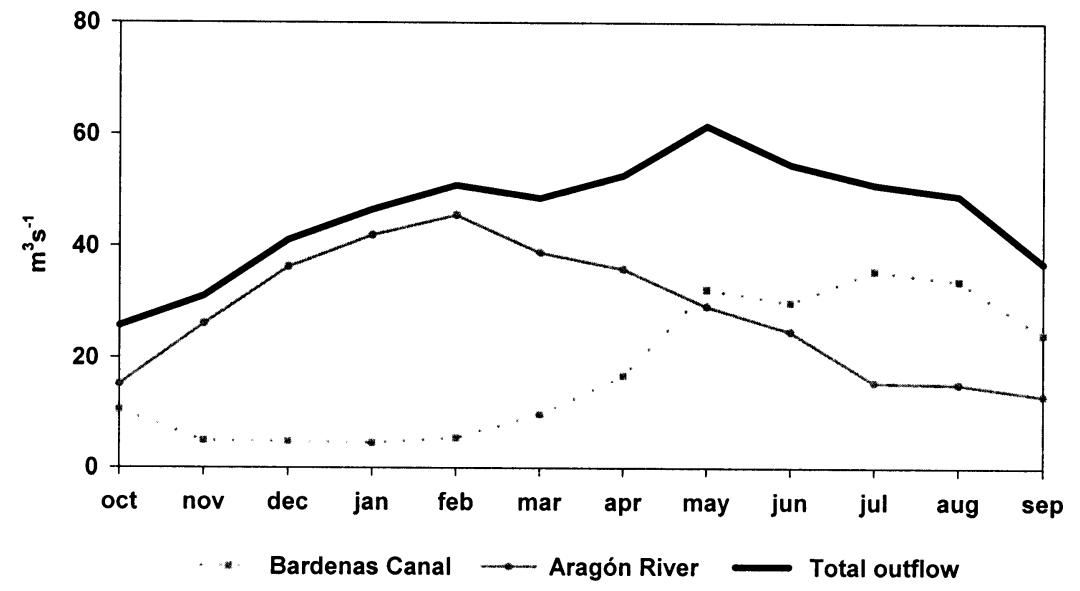

Fig.3. Mean monthly evolution of outflow from the Yesa Reservoir

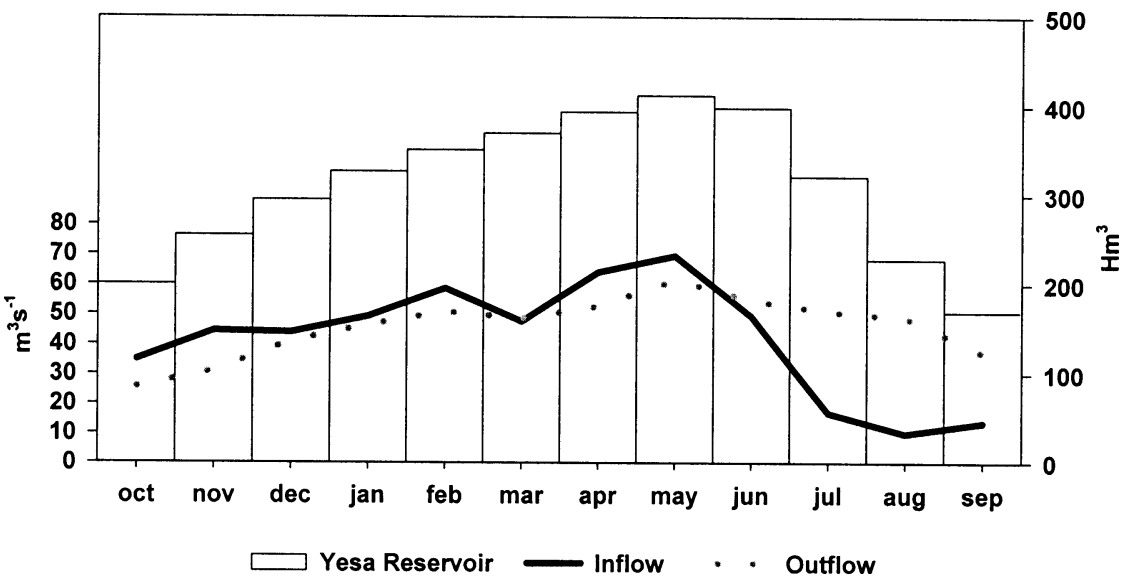

Fig.4. Average monthly volume stored in the Yesa reservoir and the balance between inflow and outflow 


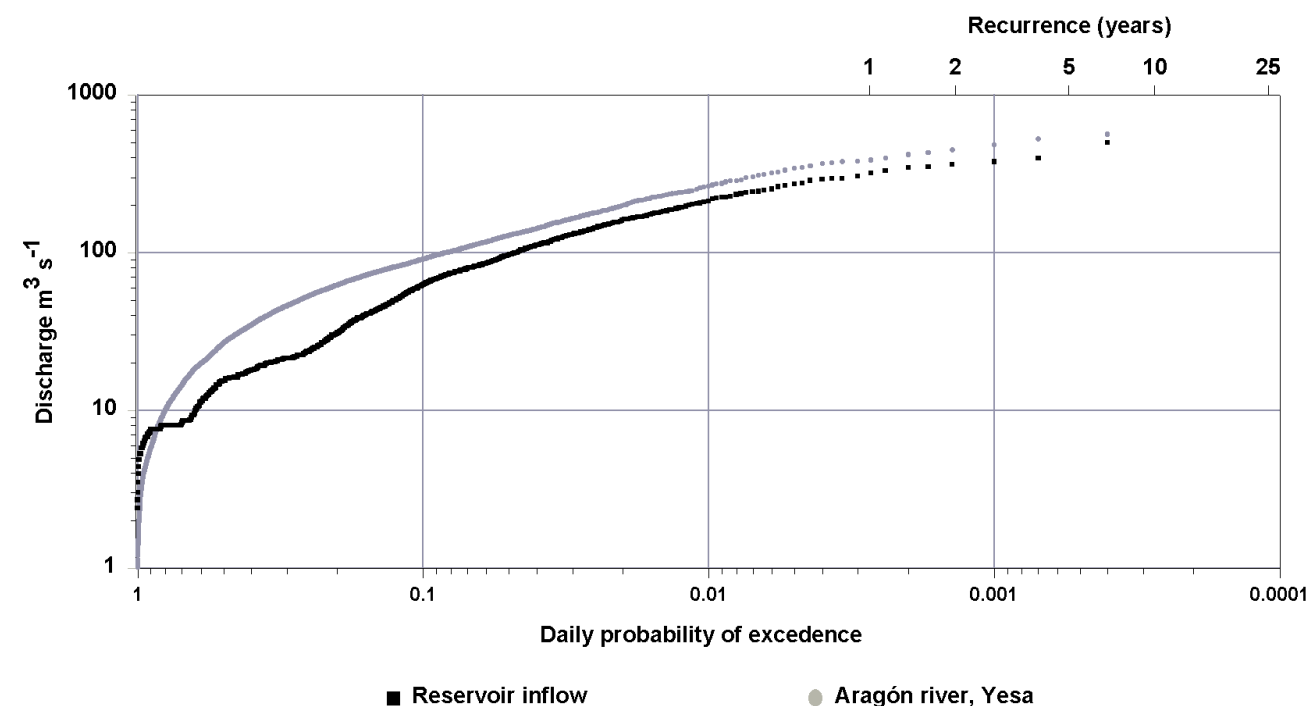

Fig.5. Frequency-intensity curves of the inflow to the Yesa reservoir and the Aragón River downstream of the dam

The difference in discharge between the curves is a consequence of diverting water to the Bardenas Canal and managing high flows. It is interesting to note that:

(i) The difference between the curves tended to decrease for low recurrence events. In the case of the Yesa reservoir, floods corresponding to a 5 -year return period decreased from $531 \mathrm{~m}^{3} \mathrm{~s}^{-1}$ to $465 \mathrm{~m}^{3} \mathrm{~s}^{-1}$, and those of a 25 -year return period decreased from $743 \mathrm{~m}^{3} \mathrm{~s}^{-1}$ to 658 $\mathrm{m}^{3} \mathrm{~s}^{-1}$. Floods corresponding to a 100 -year return period underwent very limited control, from $912 \mathrm{~m}^{3} \mathrm{~s}^{-1}$ to 844 $\mathrm{m}^{3} \mathrm{~s}^{-1}$, that is, a reduction of only $7 \%$. Figures corresponding to a more than 100 -year return period, although not sufficiently reliable to predict discharges due to changes in inflow discharges over the study period (Beguería et al., in press), have been included for comparative purposes. In relative terms, the outflow/ inflow ratio decreases as the return period increases (Fig. 6), confirming the results in Higgs and Petts (1988); they found the effect of reservoir lag and flood storage decreases as flood magnitude increases.

(ii) For very low discharges, the inflow can be lower than the outflows. The outflow was rarely below $9 \mathrm{~m}^{3} \mathrm{~s}^{-1}$, whereas the inflow might be as low as $1 \mathrm{~m}^{3} \mathrm{~s}^{-1}$ at the entrance to the reservoir. Relatively stable outflow discharges can be assessed by two steps in the curve, at around 9 and $12 \mathrm{~m}^{3} \mathrm{~s}^{-1}$, that occur preferentially in summer and late autumn, respectively.

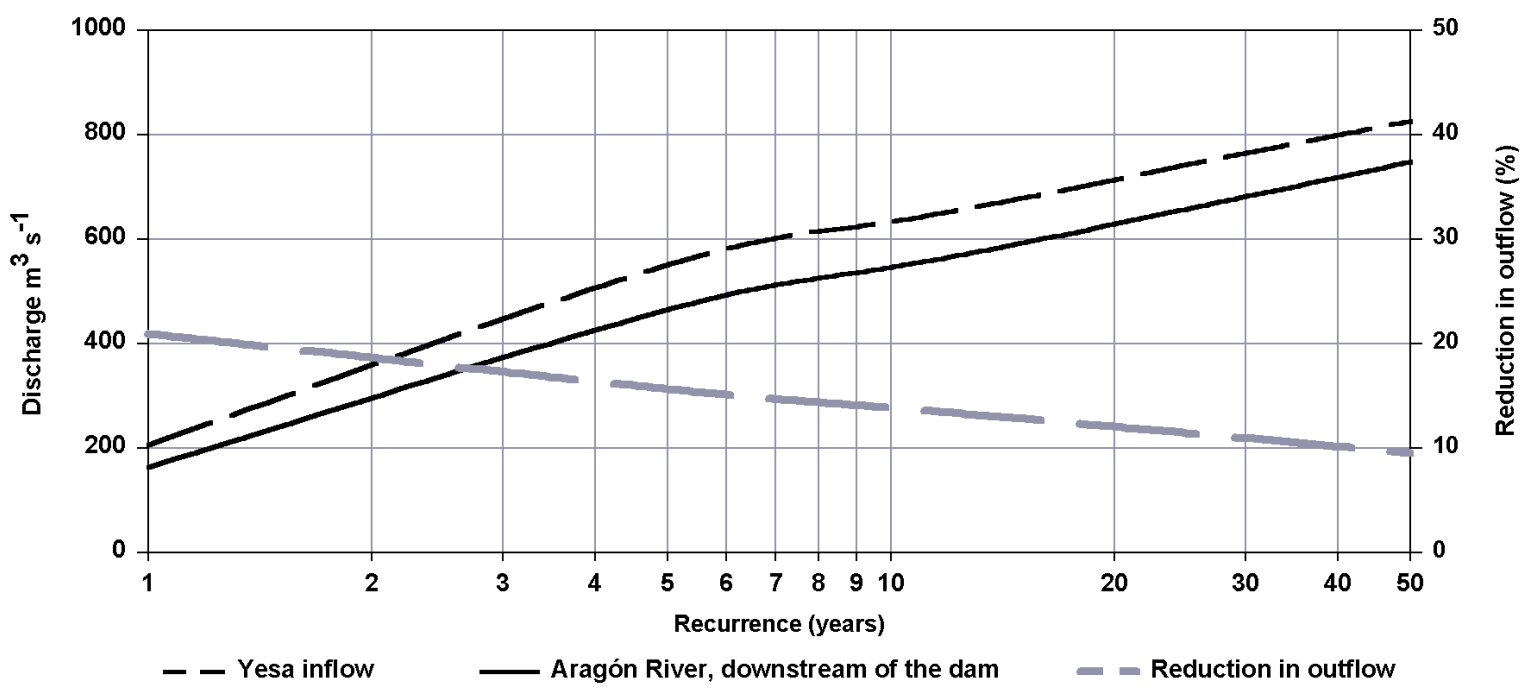

Fig.6. Return period curves of Yesa inflow and Aragón River downstream of the dam 


\section{THE ROLE OF WATER STORAGE LEVEL}

The reservoir behaves differently in respect of floods when the water storage level is considered (Pircher, 1990).

When the reservoir was below 50\% capacity (around $225 \mathrm{hm}^{3}$ or less), the flood control capacity was almost total. A rapid separation of inflow and outflow curves, confirmed that the outflow maintained the same level, even for a 100year return period inflow event (Fig. 7a).

At $70-90 \%$ capacity, flood control decreased sharply (Fig. $7 b)$. There was almost no reduction in peakflows for floods corresponding to less than a 10 -year return period and flood control for large floods (100-year return period) was limited.
Above 90\% capacity (Fig.7c), floods could no longer be buffered and the discharge corresponding to any return period was similar for both the inflow and outflow discharges. During the largest floods, the peakflow downstream of the dam was even higher than the inflow. These large floods are related to intense storms that affect the whole Upper Aragón River Basin, when reservoir managers fear for the safety of the people and fields downstream (García-Ruiz et al., 1983). Higgs and Petts (1988) also stress that peakflows downstream of a dam can be higher than upstream, especially in the case of hydropower plants.

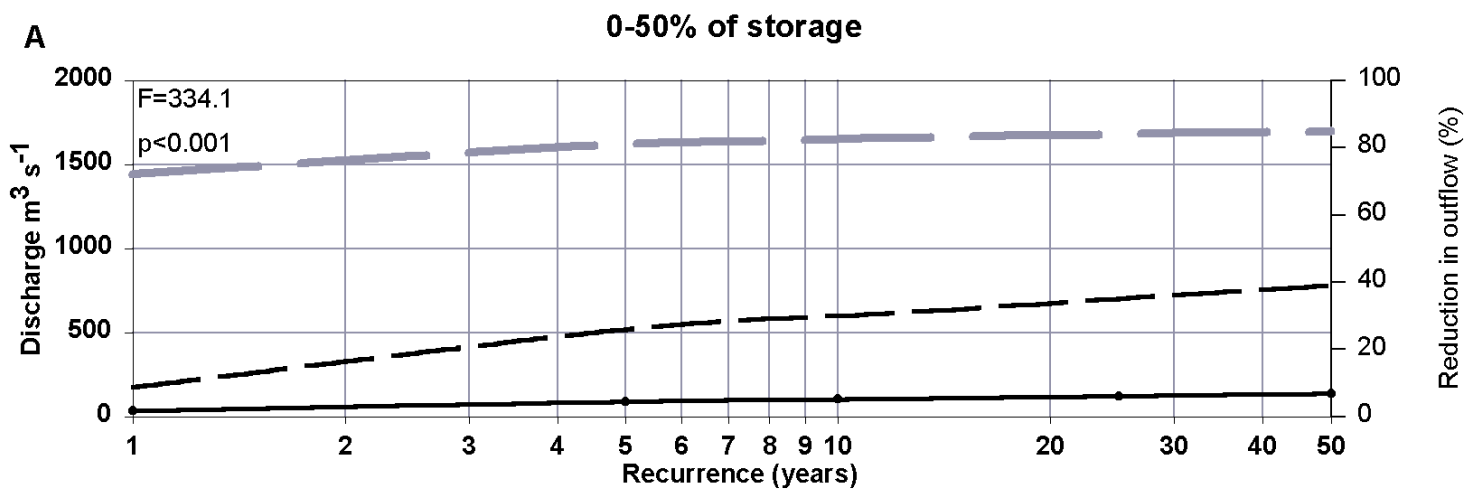

B
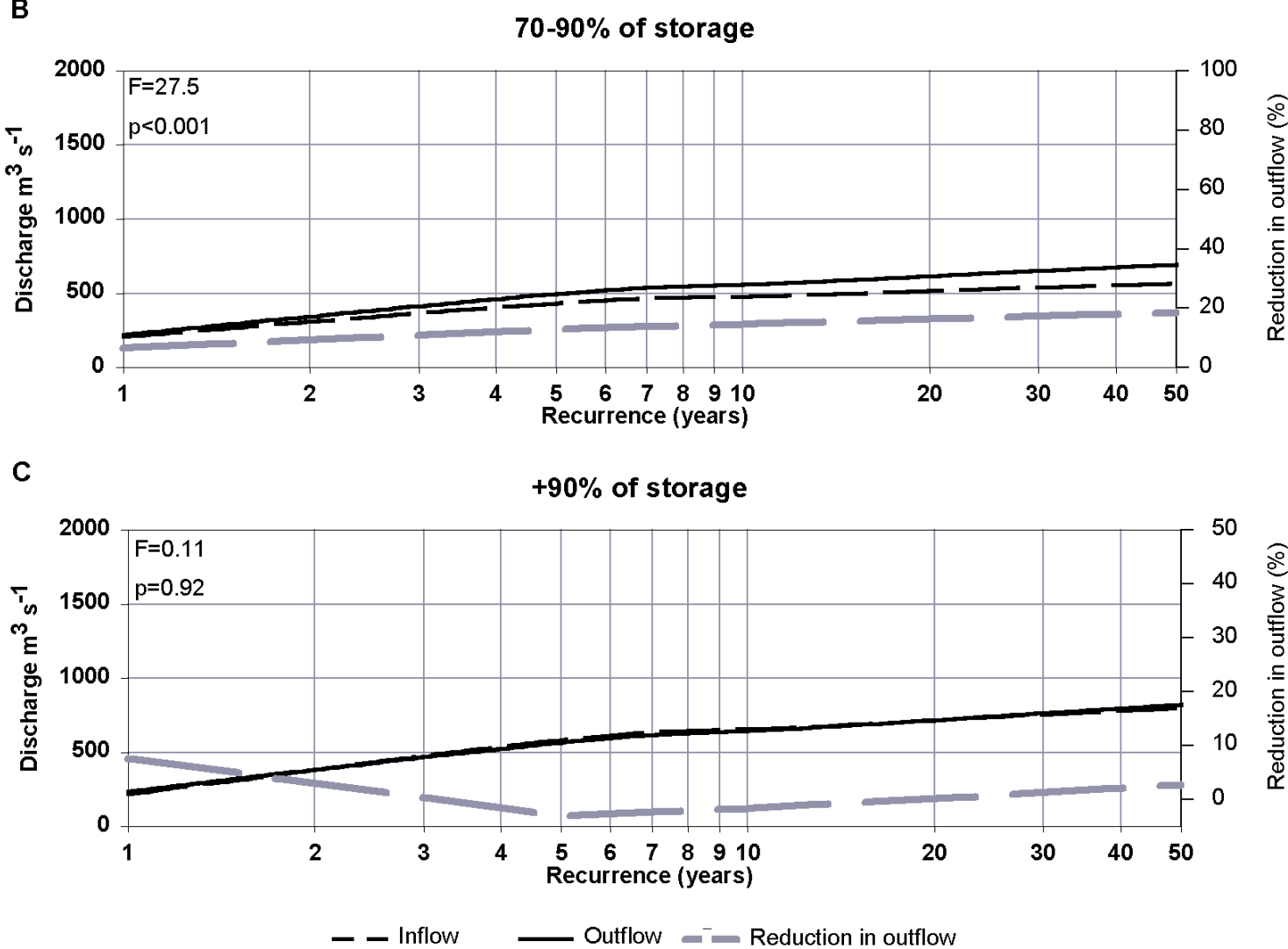

Fig.7. Return period curves for different water storage levels in the Yesa reservoir 


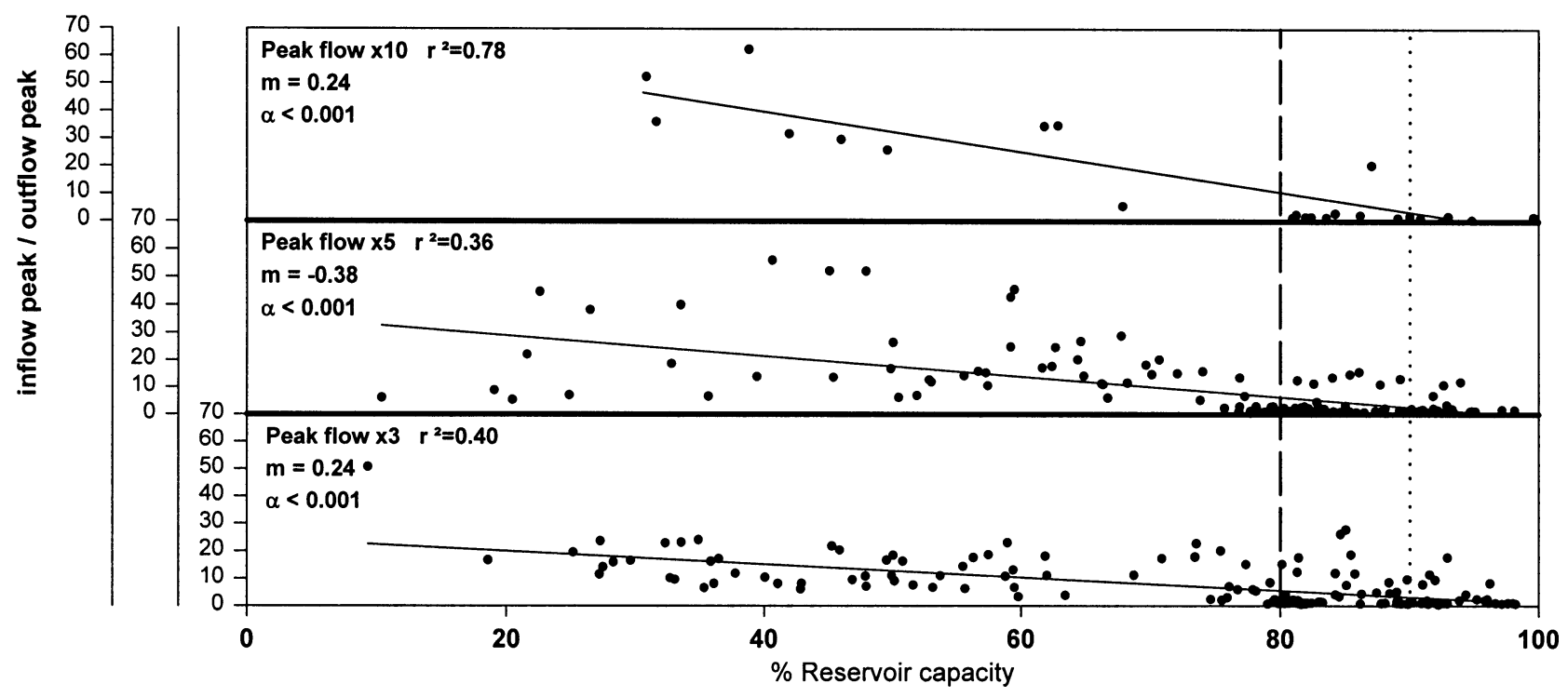

Fig.8. Relationships between the ratio inflow/outflow peaks and the water storage level, for different intensities of peak flow

Figure 8 shows the ratio between inflow and outflow discharges according to the percentage of reservoir capacity for the three types of flows; the downstream peakflow decreases more at lower than at higher water storage levels. Nevertheless, the slope of the regressions is very different for each type of flood $(-0.24,-0.38$ and -0.72 respectively; $)(\mathrm{P}<0.001)$. The coefficient of determination is high for floods exceeding 10 times the average annual discharge $\left(\mathrm{r}^{2}=0.78\right)$, and relatively poor for floods exceeding 3 times the average annual discharge $\left(r^{2}=0.40\right)$. This suggests that i) for large floods, the role of the reservoir is clearly related to the water storage level, and ii) the management of very frequent floods also depends on other factors, i.e. the season of the year or the expected snowmelt. In the case of the Danube, Zsuffa (1999) stated that the management of Austrian hydropower plants increases low and medium flows and decreases high flows.

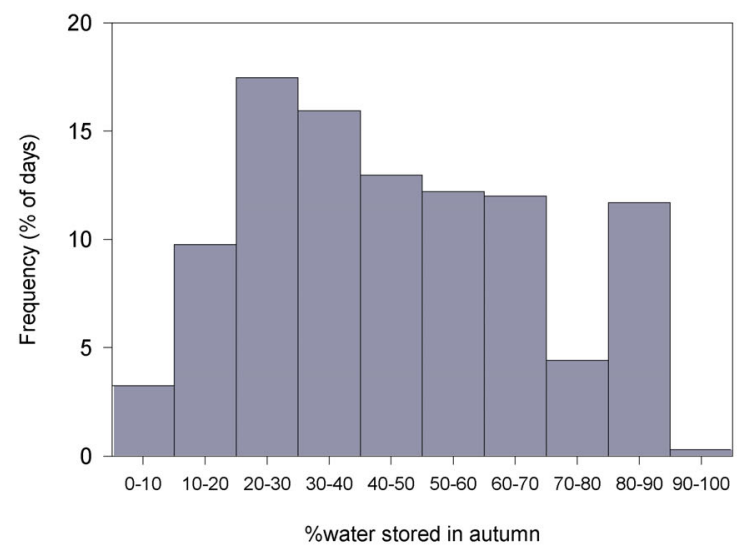

\section{THE SEASONALITY OF FLOOD CONTROL}

Water storage in the Yesa reservoir increases from October to May-June, with two main periods of refilling in autumn and spring (Fig. 4). In fact, the reservoir managers try to retain a large proportion of the autumn discharge to increase the water storage rapidly. After this, spring high flows ended the process of refilling. Figure 9 shows the percentage of water storage in autumn and spring, in relation to the total storage capacity of the Yesa reservoir. Storage is quite variable in autumn; almost any storage level is possible due to the variability of autumn rainfall in the Mediterranean environment. After summer, a long period is normally needed to re-start a rapid filling of the reservoir. In spring, the reservoir is usually at $70-80 \%$ of its capacity, especially at the end of the season. This demonstrates that responses to flooding will differ in autumn and spring.

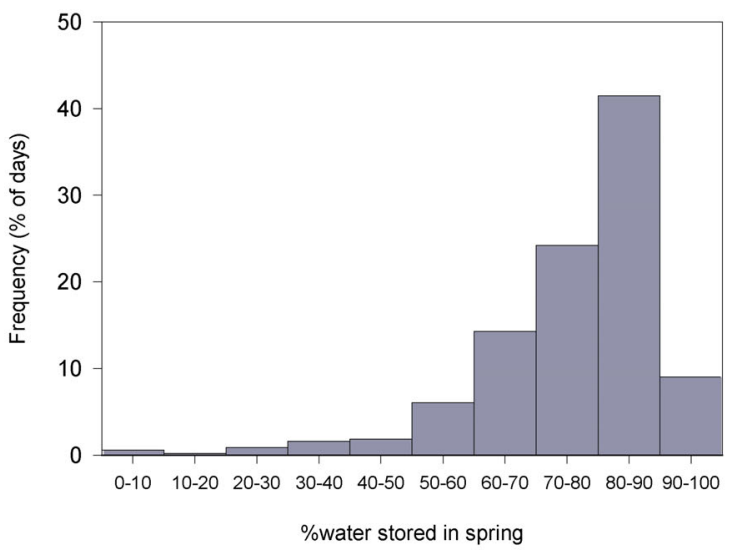

Fig. 9. Histograms of frequency of water storage level in autumn and spring 
Figure 10 illustrates the number of floods, month by month, and compares the inflows (Aragón and Esca rivers) and the outflows (Aragón river at the foot of the dam) with floods that exceed by three and five times the average annual discharge. The inflow floods occur between October and June, with very few in summer. Most floods occur in May, followed by April, February and November. Floods are infrequent in December and June, whereas the most frequent floods (only three times higher than the average) tend to occur throughout the wet season, especially in May and April.

The distribution of floods is very different downstream of the dam. Clearly, they decrease in frequency in October and November and in April, May and June (Fig. 10). There were no floods in October since the reservoir was at its lowest level, and almost the same occurred in November. The spring floods were used to complete the process of filling before summer releases. Nevertheless, the possibility of reducing a medium-sized flood in spring was lower than in autumn.

Given the regular and consistent occurrence of springtime floods (due to the regularity of snowmelt and spring rainfall), the reservoir managers rely on them to completely refill the reservoir. Hence, they release all inflow between December and March. Floods can even increase in December, February and March as water is released in anticipation of the expected spring discharges.

The seasonality of reservoir effects has also been reported in some British rivers. In the River Hodder, Higgs and Petts (1988) find that the effect of the reservoir is greater during the summer. The value of a 5-year winter peakflood decreased only by $8 \%$ after the construction of the reservoir, whereas a 5 -year summer flood decreased by $50 \%$. In Austrian rivers, reservoirs also have clear seasonal consequences for floods. The biggest floods in summer are well controlled since the reservoirs do not completely fill until September or October (Pircher, 1990).

The largest floods (over ten times the average annual discharge) almost disappear downstream, especially in winter. Table 1 demonstrates that the most frequent floods are poorly controlled in winter but the largest floods are greatly reduced. This may be a consequence of flood management in the Upper Aragón River as part of flood control for the whole Ebro River Basin. The largest floods in the Ebro river are in winter after oceanic rainfalls. The Yesa reservoir managers try to reduce the largest winter
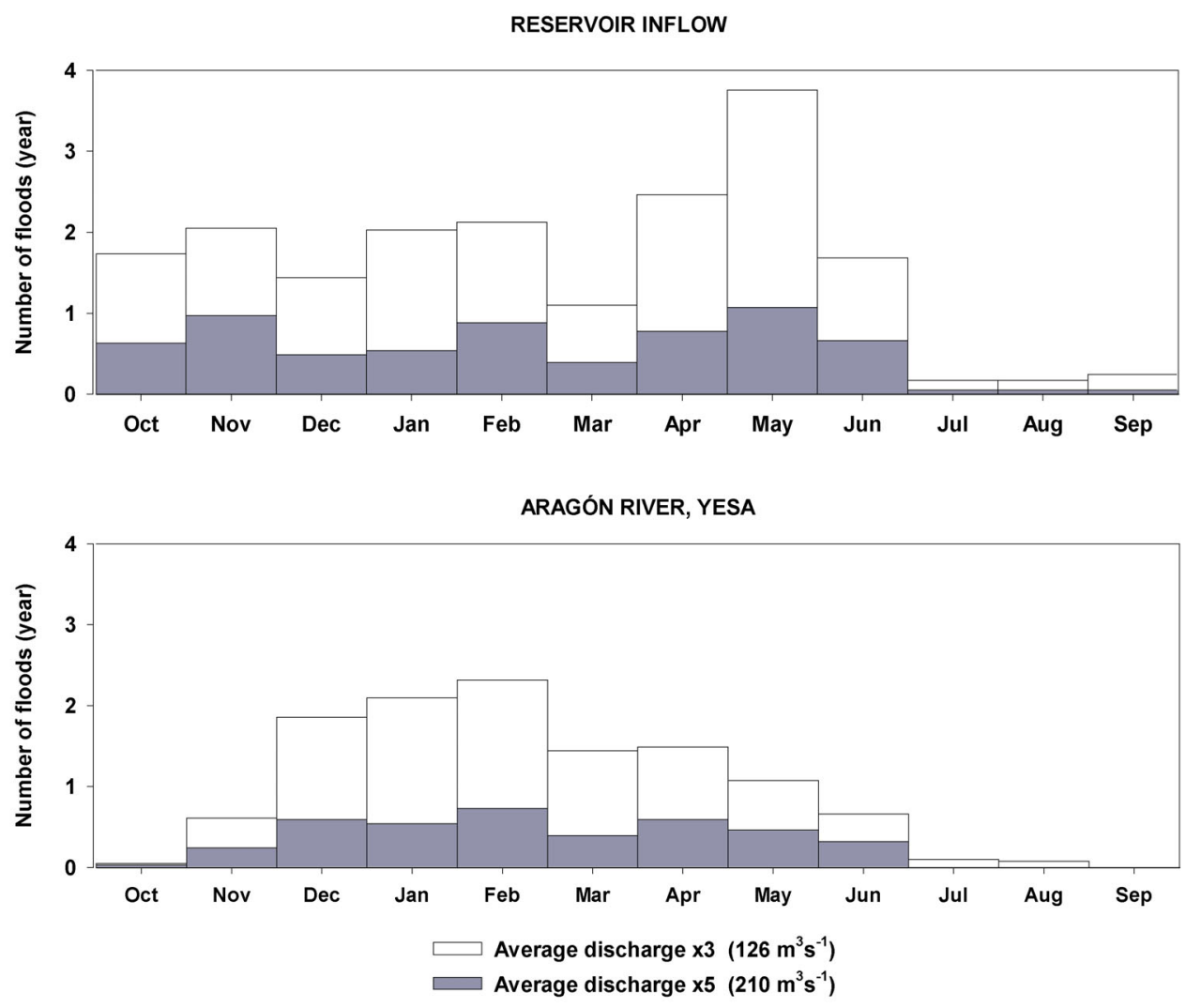

Fig.10. Frequency of upstream and downstream floods through the year. Floods exceeding 10 times the average annual discharge have been eliminated due to their low frequency 
Table 1. Seasonal percentage of flood reduction. Columns A and B indicate the number of days per year during which the dischsrge exceeds three or ten times the mean annual discharge

DischARge $\times 3\left(126.2 \mathrm{~m}^{3} \mathrm{~s}^{-1}\right)$

A. Inflow B. Outflow \% Floods reduced

\begin{tabular}{llll}
\hline Autumn & 5.20 & 1.78 & 66 \\
Winter & 6.83 & 6.39 & 6 \\
Spring & 6.59 & 3.39 & 49 \\
Summer & 0.29 & 0.20 & 33 \\
Total & 18.90 & 11.76 & 38 \\
\hline
\end{tabular}

DisCHARGE $\times 10\left(420.7 \mathrm{~m}^{3} \mathrm{~s}^{-1}\right)$

\begin{tabular}{llll} 
& Inflow & Downstream & $\%$ Floods reduced \\
\hline Autumn & 0.17 & 0.10 & 43 \\
Winter & 0.29 & 0.02 & 92 \\
Spring & 0.17 & 0.10 & 43 \\
Summer & 0.02 & 0.00 & 100 \\
Total & 0.66 & 0.22 & 67 \\
\hline
\end{tabular}

floods in the Aragón so that they do not coincide with floods in the Ebro, which would cause flooding in the lower Ebro Basin..

Finally, Fig. 11 shows that the behaviour of the reservoir with respect to autumn and spring floods is very different. The autumn intensity-frequency curves show a large separation for upstream and downstream discharges over a 30-year return period, but the relationship was reversed for the most infrequent floods. This confirms that most of the autumn floods were reduced strongly by the reservoir and that extreme floods could increase discharge due to sudden water releases. In spring, the most frequent floods were also reduced but the separation between the upstream and downstream peak flows was very small, whereas the largest peak flows were strongly reduced.
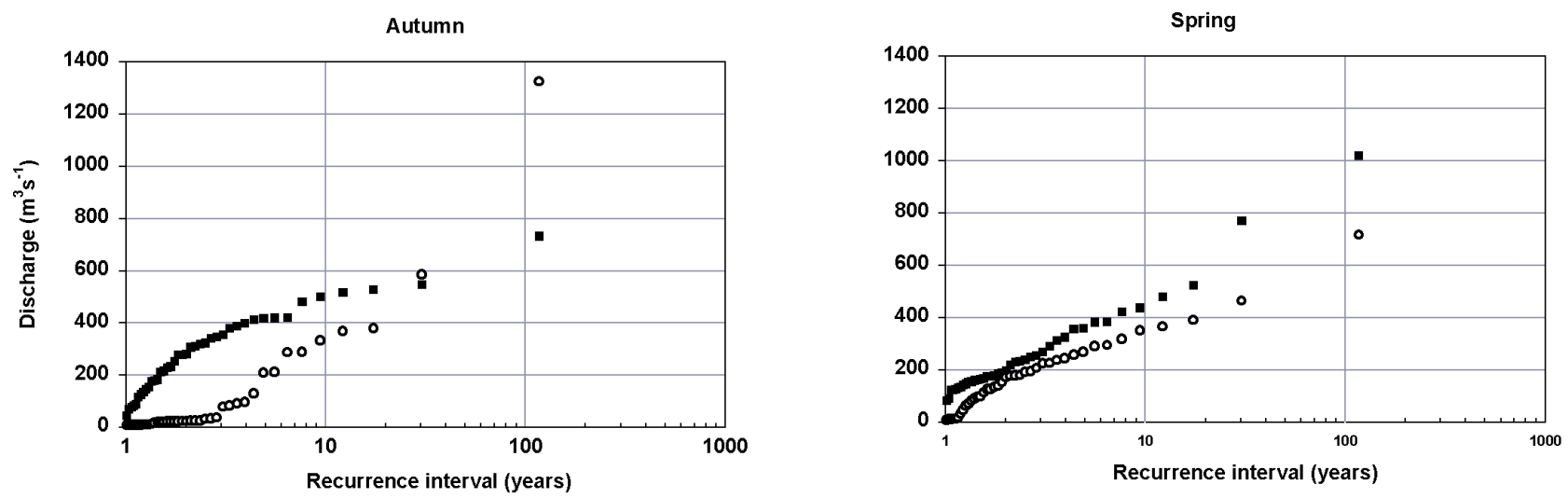

- Yesa Inflow

Aragon river, Yesa

Fig.11. Annual maximum expected peak flows in autumn and spring 


\section{Conclusions}

The role of the Yesa reservoir in reducing floods in the Upper Aragón River, and its influence on the seasonality of floods has been considered. The main conclusions are:

(i) From a comparison of upstream and downstream peak flows, flood peaks are clearly reduced but to a lesser extent for extreme hydrological events.

(ii) The ability to control floods depends mostly on the volume of water stored in the reservoir. Floods are very well controlled when the reservoir capacity is less than $50 \%$. Between 50 and $70 \%$, only the highest floods (corresponding to a $>10$-year return period) are controlled, to avoid flooding problems downstream. Above $90 \%$ capacity, there is almost no flood control and even higher peak flows can occur downstream due to sudden water releases for reasons of dam safety.

(iii) For large floods, the role of the reservoir is related directly to the water storage level, whereas there are other management possibilities for the most frequent floods.

(iv) The reservoir is refilled mainly by the autumn and spring high flows. Hence, there is a clear reduction in the number of autumn and spring floods. Most winter floods are released downstream as a safety precaution. Only the highest winter floods are controlled, to avoid any coincidence with floods in the Ebro River.

(v) Autumn floods are subject to a stronger reduction in frequency and intensity than spring floods, due to the different storage state of the reservoir in these seasons.

\section{Acknowledgements}

This work was supported by the research project "Water resources management in a changing environment: the impact of sediment in sustainability" (WARMICE, ENV4CT98-0789), funded by the European Community, and two projects funded by the CICYT "Assessment of sediment and runoff sources in relation to land-use changes" (HIDROESCALA, REN2000-1709-C04-01/GLO) and "Hydrological processes in semi-natural Mediterranean areas" (PROHISEM, REN2001-2268-C02-01/HID).

\section{References}

Beguería, S., López-Moreneo, J.I., Lorente, A., Seeger, M. and García-Ruiz, J.M.,(in press). Assessing the effect of climate oscillations and land-use changes on streamflow in the Central Spanish Pyrenees. Ambio.

CEDEX, 1988. Reconocimiento Batimétrico del embalse de Yesa. Centro de Estudios Hidrográficos, Ministerio de Obras Públicas y Urbanismo, Madrid. 63 pp.

García-Ruiz, J.M., Puigdefábregas, J. and Martín-Ranz, M.C., 1983. Diferencias espaciales en la respuesta hidrológica a las precipitaciones torrenciales de noviembre de 1982 en el Pirineo Central. Estud. Geográf., 170-171, 291-310.

García-Ruiz, J.M., Puigdefábregas, J. and Creus, J., 1985. Los recursos hídricos superficiales del Alto Aragón. Instituto de Estudios Altoaragoneses, Huesca. 224 pp.

García-Ruiz, J.M., Puigdefábregas, J. and Creus, J., 1986. La acumulación de la nieve en el Pirineo Central y su influencia hidrológica. Pirineos, 127, 27-72.

García-Ruiz, J.M., Beguería, S., López Moreno, J.I., Lorente, A. and Seeger, M., 2001. Los recursos hidricos superficiales del Pirineo aragonés y su evolución reciente. Geoforma Ediciones, Logroño. $192 \mathrm{pp}$.

Higgs, G.P. and Petts, G., 1988. Hydrological changes and river regulation in the UK. Regul. Rivers, 2, 349-368.

Hosking, J.R.M., 1990. L-moments: Analysis and estimation of distributions using linear combinations of order statistics. J. Roy. Statist. Soc., Series B, 52, 105-124.

Jiongxing X., 1990. Downstream hydrological effects of reservoirs built in mountainous areas and their environmental influences. In: Hydrology in Mountainous Regions. II Artificial Reservoirs: Water and Slopes, O. Sinniger and M. Monbaron, (Eds.), IAHS Publ. no. 194, 187-194.

Lee, K.T., Chang, C.H., Yang, M.S. and Yu, W.S., 2001. Reservoir attenuation of floods from ungauged basins. Hydrolog. Sci. J., 46, 349-362.

López-Moreno, J.I., Beguería, S. and García-Ruiz, J.M., 2000. El régimen del embalse de Yesa (cuenca alta del río Aragón, Pirineo central) y su adaptación a la variabilidad del régimen fluvial. Cuadernos Invest. Geográf., 26, 131-145.

Madsen, H., Pearson, C.P. and Rosbjierg, D., 1997. Comparison of annual maximum series and partial duration methods for modelling extreme hydrologic events. 1: At-site modelling. Water Resour. Res., 33, 759-769.

Pircher, W., 1990. The contribution of hydropower reservoirs to flood control in the Austrian Alps. In: Hydrology in Mountainous Regions. II Artificial Reservoirs: Water and Slopes, O. Sinniger and M. Monbaron, (Eds,), IAHS Publ. no. 194, 3-10.

Takeuchi, K., 1998. Current status of reservoirs: Number, size and shape of reservoirs. In: Sustainable reservoir development and management, K. Takeuchi, M. Hamlin, Z.W. Kundzewicz, D. Rosbjierg and S.P. Simonovic, (Eds.), IAHS Publ. no. 251, 4-7.

White, S., García-Ruiz, J.M., Martí-Bono, C., Valero, B., Errea, M.P. and Gómez-Villar, A., 1997. The Biescas campsite disaster and its temporal and spatial context. Hydrol. Process., 11, 17971812.

Zsuffa I., 1999. Impact of Austrian hydropower plants on the flood control safety of the Hungarian Danube reach. Hydrolog. Sci. J., 44, 363-371. 